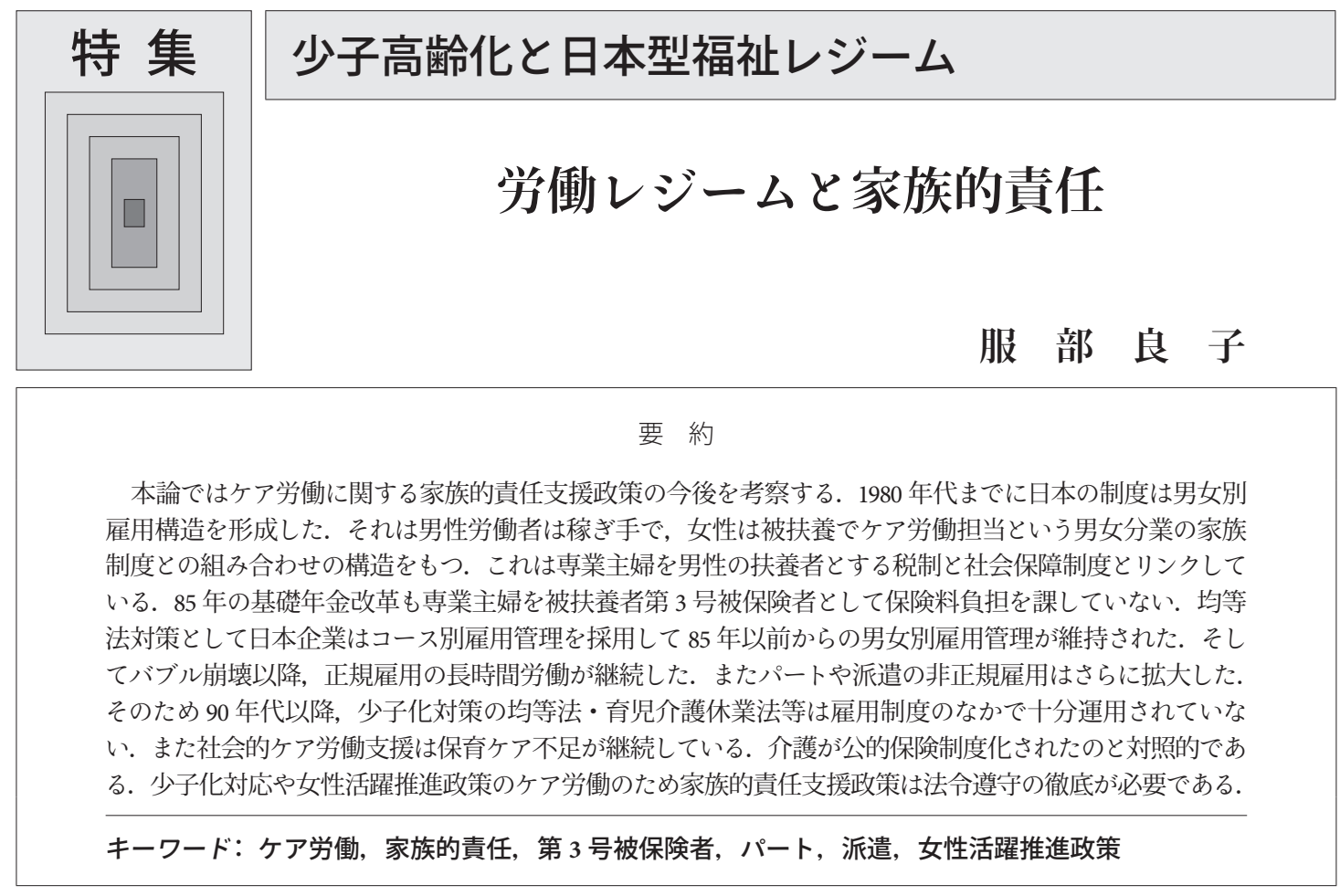

2015, 家族社会学研究, 27(1)：36-48

\title{
Japan's Employment System and Family Responsibility
}

\section{Ryoko Hattori}

\section{Abstract}

This paper analyzes the effects of Japan's family responsibility support policy related to care work. A gendersegregated structure was formed in the Japanese employment system where the male worker was the breadwinner and the female was the caregiver in a family. This structure was linked to the tax system and the social security system, in both of which the male breadwinner supported the full-time housewife. The 1985 reform of the national pension system introduced "Category III insured persons" that did not need to pay contributions. The gender-segregated structure against the Equal Employment Opportunity Law introduced a course-based personnel management system to keep the gender-segregated structure. The collapse of the bubble economy brought longer working hours and more non-regular work for people as part-timers or temporary workers. Positive action policies for children and working mothers and father could not be utilized sufficiently in the employment system.

Key words: care work, family responsibility, Category III insured persons, part-timer, temporary worker, positive action policy 


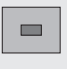

\section{I. はじめに}

アベノミクスのなかで, 女性活躍推進は主要な 柱の一つとされ, 成長戦略の中核とうたわれてい る。あわせて出産子育てしながら女性が働き続け られる社会の実現に, 男性の子育てのよりいっそ うの「参加」推進も言及されている. 少子高齢化 が進行する現在, 首相と政府が認めるところの女 性が産みにくく女性も男性も子育てしにくい2 世紀の日本社会の現状は, 日本の働き方に最大の 原因がある。働き方とその制度や政策の総体であ る労働レジームは, 男女労働者の雇用形態や労働 基準規制を通じて，直接間接に育児や介護のケア 労働責任である家族的責任のありかたを左右して いる日本の現状がある（塩田 2000; 竹中 2012a, b).

1965 年の ILO123 号勧告では「家庭責任をもつ 婦人」が明記されていた。 60 年代には欧米でも 家族的責任はまず女性に帰するものであった。そ の後 1975 年からの「国際婦人の 10 年」の半ば, 1981 年, ILO156 号条約は男女の労働者を「家族 的責任を有する労働者」と規定した。なお家族的 責任の中核は，家族のための育児や介護というケ ア労働負担である. 1980 年代以前に男女の労働 役割分担を前提とした〈分業型〉家族的責任は, ILO156 号条約とともに男女が共に家族的責任を 担う〈シェア型〉への転換が始まった（服 部 1997, 2007).

この背景には, グローバル経済の本格化に先立 ち, 先進工業国での労働力の女性化の進展が目立 ち始めた状況がある。女性が社会での仕事に従事 すれば，家庭での家事育児介護の二重負担課題が 生ずる. 女性の二重負担は, 女性の出産抑制, 少 子化という結果を導きつつあった。 女性の就労が 少子化の原因とされた。ところが，1990年代末 から労働力の女性化が出生率低下をもたらした現 象とは逆に, 女性労働力率の上昇のある諸国の一 部で出生率の上昇が, 2000 年以降確認され始め る.この変化は, とりわけフランスや北欧で顕著
で，家族的責任支援の社会政策の影響が大きい. すなわち, 保育や介護などケア労働を社会サービ スとして提供し, ケア労働のための休㗇制度や短 時間勤務を可能にする制度導入である。とりわけ 女性の両立支援にとどまらず，男性も育児ケア労 働を担うことが可能な「シェア型」家族的責任支 援制度の社会政策運用であった。

これに対し, 一定の女性労働力率の上昇は確認 しながらも，対照的に同時期に引き続き出生率は 低下を続けた国々がある。すなわち日本をはじめ イタリア，ドイツでは，家族的責任支援の社会政 策については「シェア型」の運用ではなく男女の 「分業型」であった。そこでは, 男女両性に対す る両立支援ではなく，主に女性の両立支援政策と して制度運用がされていた。日本では出生率戦後 最低の 1.57 ショックを受けて, 少子化対策の「エ ンゼルプラン」として 1990 年から「女性のため の両立支援」政策が打ち出された。加えて 1997 年均等法改正によるポジティブ・アクションの導 入も，まず女性の両立支援の法的裏づけという役 割であった。上昇しない出生率対策と女性活躍推 進のためにワーク・ライフ・バランス憲章（WLB 憲章）が 2007 年に定められた。

WLB 憲章では行政と企業を政策主体として位 置づけたため,〈シェア型〉家族的責任支援政策 が本格化されるかにみえた。実際に次世代育成支 援対策法によって企業の行動計画策定が定められ たからである。しかし 2010 年代の日本では, 法 制度運用では〈分業型〉家族的責任体制が変わら ずに優先維持されている。 それを最も象徴するの は，男性の育児休業取得率の低さである。また， 法的には非正規雇用にまで母性保護や育児休業取 得適用を広げたにもかかわらず，その適用を阻む マタニティ・ハラスメントの頻発であった。〈分 業型〉の女性の両立支援政策適用すらいまだ進ん でいないのが日本の職場である.

日本の職場での働き方は, 1980 年代には日本 的経営といわれる日本的雇用制度である労働レ ジームのもとにあった。石油や多様な天然資源に 
特集 少子高齢化と日本型福祉レジーム：労働レジームと家族的責任

は恵まれない日本が，敗戦後わずか数十年で高い 経済力を獲得した源泉は, 絶えざる技術革新を実 現し高品質の製品を作ることのできる人材と安定 した雇用関係および労使関係にあるとみなされて いた。とりわけ日本的雇用制度は，終身雇用とい われる長期雇用保障，年功カーブを示す賃金，そ して企業内組合の存在を特徴としていた（大 森 2014). 高度成長期に労衝力不足を背景に形成 された日本的雇用制度は, 同時に国家による家族 単位の社会保障とそれと補完関係をもつ企業の雇 用管理政策と密接に連動して機能してきた（服部 1993, 1994).

ただ 2000 年代の日本では流動性の高い非正規 雇用の労働市場の拡大に注目が集まり，これらの 特徵は薄れた感もある。しかし，1991年のバブ ル崩壊後の 10 年以上続いた長い不況期は，むし ろ日本的雇用制度の維持存続のための多様な調整 過程であった。本論では, 日本的雇用制度の中で 家族的責任とされるケア労働負担が 21 世紀にも 引き続き女性に比重をおく〈分業型〉として維持 される経緯について, 90 年代以降の雇用状況と 女性の両立支援政策の変遷をろりかえることから
考察する.

\section{II. 日本の家族的責任の現状}

家族的責任をめぐる状況は働き方の指標に端的 に表れている（図 1)。まず日本の女性の年齢階 層別労働力率は, 2010 年代も $\mathrm{M}$ 字型労働力率を 継続している（図 2)。OECD 諸国の中では日本 以外に韓国だけが $\mathrm{M}$ 字型労㗢力率を保っている. 日本でも韓国でも出産育児に際して女性は就業継 続をあきらめる。その理由はまず保育ケアサービ ス供給不足であり，ついで夫のケア労働参加が困 難なことである。2000 年代の 10 年間で $\mathrm{M}$ 字の 底はわずかに上がっている。とはいえ女性のみに $\mathrm{M}$ 字型が明瞭に存在することは，女性への育児 ケア労働比重の偏りを示すといえよう．家族的責 任支援政策として 1992 年に制度化された男性育 児休業の取得率は, 男女が取得可能な法制度にも かかわらず，男性の取得率は制定後 20 年経過し た 2010 年代でも $1 \%$ 余りである.

さらに，ケア労働を含む生活全体について時間 をみるとき，家事育児介護時間の男女差が際立っ ている（図 3).21 世紀の WLB 憲章のある社会
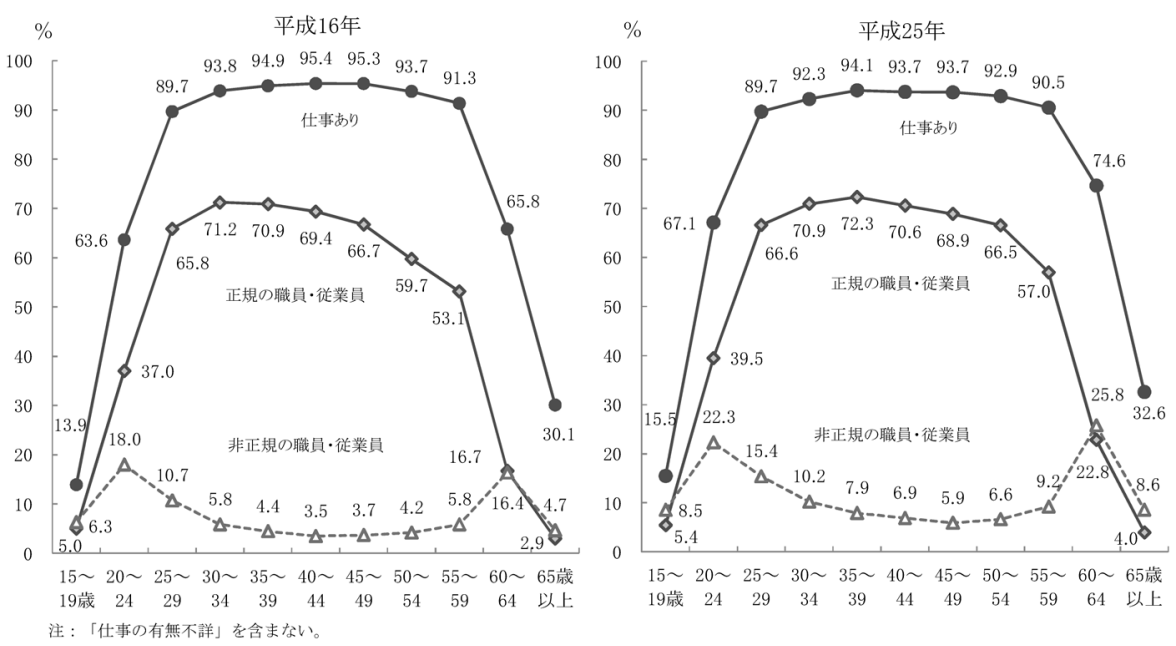

非正規雇用は女性に比べると少ない。しかも若年と高齢者に偏る。30歳代から 50 歳代の正規雇用率はきわめて高い. 出典「図 11 年齢階級別にみた 15 歳以上の男の仕事ありの構成割合」『平成 25 年度国民生活基礎調査』, 厚生労働省 ホームページ（2015 年 1 月 25 日取得 http://www.mhlw.go.jp/toukei/saikin/hw/k-tyosa/k-tyosa13/dl/16.pdf).

図 1 男性の就労状況（2004 年と 2013 年） 

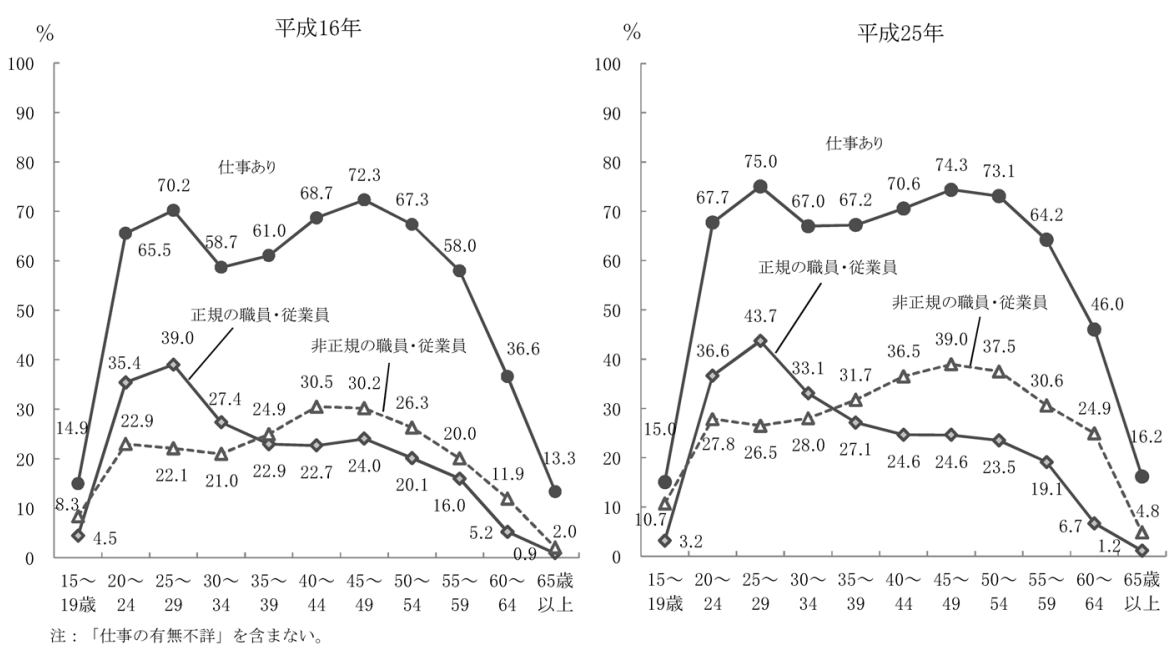

$\mathrm{M}$ 字型労働力率は継続． $\mathrm{M}$ 字の底は上がったが，非正規雇用が増加した女性雇用．しかも若年層は正規，中高年層 は非正規に分離した分布を示す。

出典「図 11 年齢階級別にみた 15 歳以上の女の仕事ありの構成割合」『平成 25 年度国民生活基礎調査』，厚生労働省 ホームページ（2015 年 1 月 25 日取得 http://www.mhlw.go.jp/toukei/saikin/hw/k-tyosa/k-tyosa13/dl/16.pdf).

\section{図 2 女性の就労状況（2004 年と 2013 年）}

にもかかわらず男性の家事・育児合わせても 1 時 間以下である。なにより，共働き夫婦の生活時間 配分をみると，わずか 7 分であるがむしろ妻が無 業の夫の育児時間は共働きの夫より長い。男女の 働き方, 仕事時間, 家事育児時間が 1980 年代半 ばから 2010 年代までほぼ同じ配分構造を示して いることは，後に示すさまざまな政策が働き方に ほとんどインパクトをもたなかったことを物語 る. 1980 年代以降, 男性は家事育児をあまり行 わず長時間労働に従事する働き方を 2010 年以降 も変えていない。こうした男性の配偶者の女性は 家事育児時間が長く，賃金労働の時間は短くな る.

ただ高齢者に対するケア労働は異なる状況にあ る. 2000 年の介護保険法により高齢者ケアは社 会保険制度によって給付されるようになった。高 齢者ケアの家族的責任支援政策は国家がバック アップして市場から個人へケア労働が社会サービ スとして提供される仕組みが形成された。いろい ろな課題はあるとしても介護の社会化は成立して いる。これに対して子どもに対する保育ケアの家
族的責任支援政策は，圧倒的な供給不足が継続し ている．1970 年代から 2010 年代までも待機児童 問題は継続している。1990年代に，介護保険制 度に向けた高齢者ケアの社会化つまり社会保険制 度化の国民的ともいえる運動が起こった。そして ケア労働を担う女性だけでなく，政治，行政，企 業も巻き込んだ運動は国を動かし介護保険制度が 実現された。

しかしほぼ同時期，少子化が深刻化したにもか かわらず，子どものケアについて国民的運動は形 成されていない，老いとケア労働問題は男女に等 しく訪れる。それに対して，保育ケア問題は働く 女性しかも主に正規雇用の女性にとってだけの課 題であるという対立構造も確かにあった。さらに 教育費の受益者負担など子育ては親の自己責任と する論を背景に，保育ケアは限定された期間のご く一部の女性の問題であるとみなす日本社会の意 識は根強い。女性は個人の課題として，また個々 の家族として保育ケアに対応す心゙きという社会意 識が形成され，それは日本の職場における意識風 土の基盤にもなっている. 結果, 1980 年代以降, 

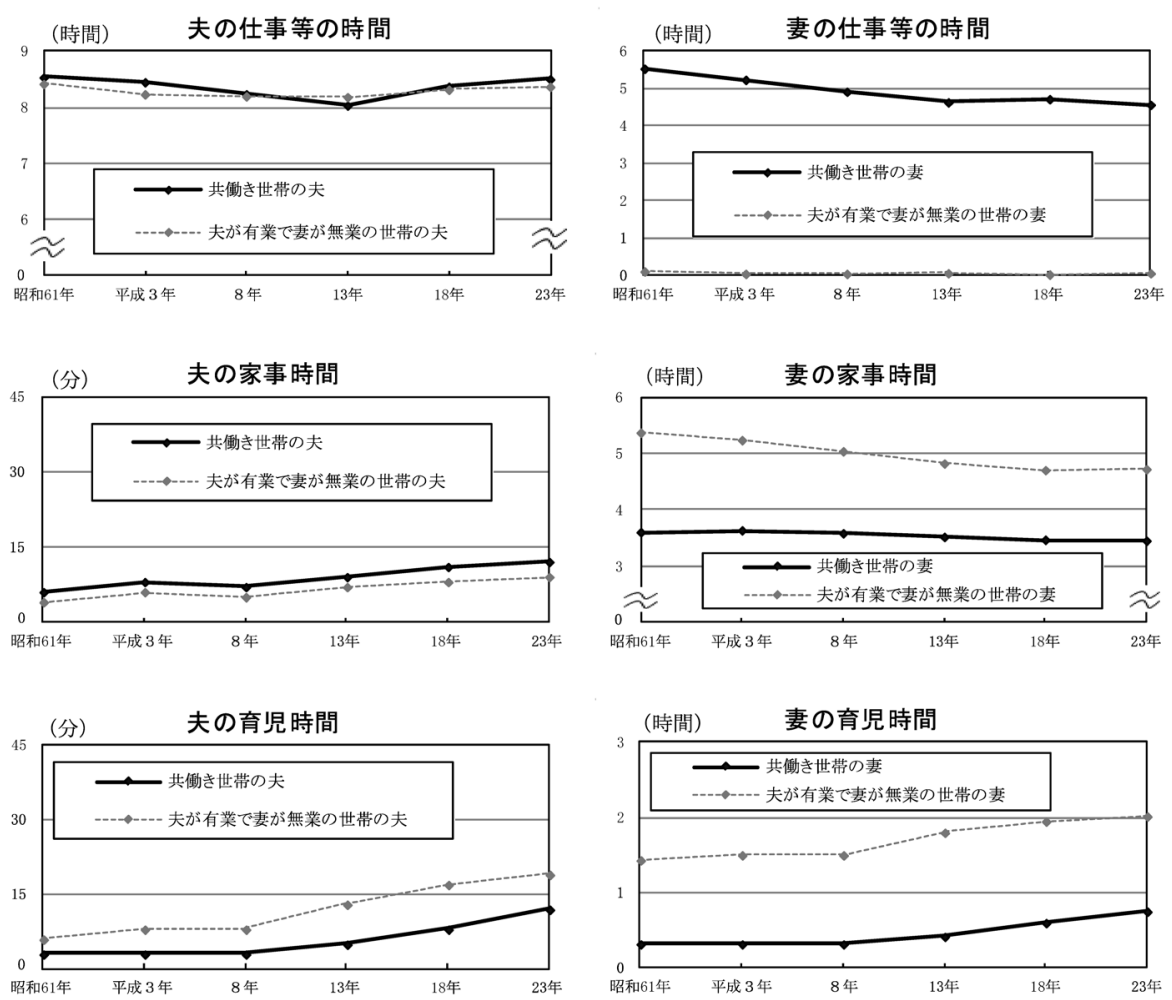

共働きか否かを問わず，日本の子育て家族では男女雇用機会均等法施行の 1986 年から 2011 年までの間，仕事・家 事・育児時間の時間配分の変化は乏しい.

使用資料出典「図 5-5 共働きか否か, 行動の種類別生活時間の推移（昭和 61 年〜平成 23 年）一週全体，夫婦と子 供の世帯の夫・妻」『平成 23 年社会生活基本調査の概況』, 総務省ホームページ（2015 年 1 月 25 日取得 http://www. stat.go.jp/data/shakai/2011/pdf/gaiyou2.pdf).

図 3 1986 2011 年の共働きの夫と妻の生活時間（仕事・家事・育児）

第 1 子出産後退職する女性はむしろ近年増加傾向 にある。それに呼応するように 1980 年代から継 続して 2010 年代でも男性が長時間労働に従事し, 男性の家事時間や育児時間は長くならない。ケア 労働の男女間で分業構造を支持し維持する社会意 識が維持され高齢者ケアと保育ケアに対する社会 意識の差が生じている。こうした「分業型」家族 的責任は, 労働レジームとそれをめぐる制度変遷 も梁く関与している.以下, 1980 年代以降のい くつかの政策の節目を確認していく.

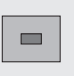

\section{1980 年代の労働レジーム}

1980 年代は, 高度成長と石油ショック, そし
て低成長を経てバブル経済という拡大期であっ た。この時期に大企業を中心に確立された日本的 経営といわれる日本的雇用制度は, 長期雇用を前 提に配置転換・転勤など異動に基づくキャリア形 成を確立していた。また長期雇用は若年期の低顀 金と中年以降の賃金上昇を組み合わせた年功的賃 金上昇を伴い，ライフステージに応じた生活保障 給の意義もあわせもった。この雇用保障と年功的 賃金上昇は企業内組合による協調的労使関係に よっても支えられた．男性の年功的賃金は家族の 生計費を支える水準要求や各種手当給付が労使交 涉を通じて満たされることによっても達成され た。 
ただしこうした雇用慣行の対象は主に大企業 の男性に限られた。中小企業の労働者は企業間の 流動性が高く, 大企業男性に比べて相対的に勤続 年数は短く年功的賃金とは限らなかった。また女 性は結婚出産で労働市場を退出するため長期雇用 や年功的賃金ではなかった（服部 1996）.

1985 年の男女雇用機会均等法制定は, 女性に 対して男性と同じ処遇を求める法制度であると産 業界は受け止めた。そこで均等法への対応として 産業界は, 80 年代までの男女別の分業型の働き 方＝男女のジェンダー分業を前提とした雇用管理 を維持するためにいわゆるコース別雇用管理を導 入した、均等法が性別による雇用管理を法によっ て禁じたため, コース別雇用管理は男女でなく総 合職と一般職とキャリアと処遇によってコースを 分けた．つまり男性と同様の働き方を受け容れる 意思を示した女性は総合職コースに配置された。 しかし，ほとんどの企業では男性は総合職コー ス, 女性は一般職コースへ振り分けることによっ て従前からの男女別雇用管理を維持した。

その結果, 1985 年の均等法制定以後も日本的 経営（長期雇用, 年功賃金, 企業内組合）の特徵 を備えた「男性稼ぎ手」モデルは, 総合職男性の 働き方として維持されることになった。キャリア 形成・生活保障給賃金カーブのある総合職は, 従 来の男性型キャリアの働き方である。総合職の キャリア形成は，長期育成型であり，転勤を伴う 配置転換が必須であり, 転勤は総合職への踏み絵 であった。 それに対して, 一般職は従前のように 結婚や出産で退出が前提とされた女性向けのキャ リアコースであった。

日本的経営としての労働レジームが, 均等法に コース別で対応したのは,「男性稼ぎ手」が「女 性被扶養者」とセットになった「家族単位型税・ 社会保障モデル」を内包していたからである。こ れこそいわゆる「家族主義的日本型福祉レジー ム」である. 男性稼ぎ手が家族単位で, 課税され 社会保険料を支払うことにより, 税や保険料を負 担できない無収入の妻や子どもたちに社会保障の
セーフティ・ネットをかけていた（服部 1993， 1994).

したがってコース別キャリアは，社会保障制 度・税制と連動している（図 4)。とくに均等法 と同じ 1985 年制定の基礎年金制度が「家族単位 型税・社会保障モデル」に与えた影響は大きい. 基礎年金制度では, サラリーマンの夫の被扶養者 である第 3 号被保険者の妻は保険料支払いから免 除されている。しかしながら，年金受給権は与え られた。また，同じ被扶養基準に基づく課税にお ける配偶者控除は, 被扶養の配偶者について, 家 計単位の節税と保険料節約のメリットをもたらし たのである. 1987 年の配偶者特別控除（2003 年 廃止）も同様である。「女性被扶養者」は家族の なかで育児や介護, 家事の担当者であるととも に, 非課税と保険料負担が発生しない範囲の年間 所得でパートタイマーとなる。雇い主にとって, 彼女たちは社会保険料負担がない低コストすなわ ち低賃金労働者という存在である.

その結果, 1985 年, 労働レジームの中核とし て引き続き確立されたのが,「男性稼ぎ手」と 「女性被扶養者」による家族である. そしてそこ での家族的責任としては，〈稼ぎ手賃労働担当男 性, 家族ケア労働十家計補助パート担当女性〉で 構成される分業型家族的責任であった. 85 年の 均等法制定は, 女性差別撤廃条約批准の前提の一 つであったが，もう一つの前提である女性の年金 権の確立は, 税・社会保障の点では, むしろ女性 被扶養者モデルを制度化する結果となった，税や 社会保険料を払うほど所得がない女性や，無収入 の女性の年金権を保険料負担なしに付与したこと は,「女性被扶養者」を女性パートという低コス ト労働力として労働レジームへ組み込む根拠を確 立することになった。 女性被扶養者二主婦は, 課 税されない労働者の地位を, 皮肉なことに女性差 別撤廃条約批准のための均等法制定という契機に よって社会保障的根拠を与えられたのである.そ れは，低コストの女性労働を組み込んだ改訂版日 本的経営あるいは 85 年型日本的雇用制度と呼ぶ 
特集 少子高齢化と日本型福祉レジーム：労働レジームと家族的責任

ことができる労働レジームの出現でもあった。こ の労働レジームは, 90 年代以降維持され 21 世紀 の日本でも労働レジームの主要基幹要素として機 能している.

\section{IV. バブル崩壊後の正規雇用}

\section{1. 雇用コア部分の縮小}

80 年代後半のバブル経済は 91 年のバブル崩壊 を経て，1990年代以降の長い低成長期へ入る. この時期に定着が進んだのが, 日本的雇用慣行の 一部変更である 85 年型日本的雇用制度であった. すでに 80 年代には日本的雇用慣行による年功賃 金の賃金コスト負担の大きさや，長期雇用による 労働力の流動性の低さは解決すべき課題として指 摘されていた。これらの課題対応はバブル崩壊に よる企業リストラとして 90 年代以降急激に進む. すなわち男性長期雇用傾向の縮小, 年功的賃金の 見直しである。その論理を端的に示すのが 1995 年の日経連報告書「新時代の日本的経営」であ る，雇用流動化とともに能力主義導入を図るべき という趣旨で, 正社員は増やさず, むしろ正社員 を相対的に縮小する労働レジームの変更だった。 これは日本的経営の中核コア労働者=成年男性労 働者の縮小にほかならない.

バブル経済の崩壊は,「長期雇用，年功賃金」 の変更が高賃金中高年のリストラとして能力主義 導入によって進められた。 また, 社宅や保養所廃 止，扶養手当給付基準見直しや廃止などによって 実質賃金が削減された。フリンジベネフィットに 代表される「日本型福祉レジーム」であった手厚 い福利厚生が縮小廃止された。削減されたコア労 働者は, 社外へ排出され一定部分が, パート, 派 遣労働者など非正規雇用者などとなっていった。

同時にコアの縮小は新規学卒者採用の縮小とし ても進行する. 採用絶対数の削減に加え正規雇用 の一般職職種の縮小または廃止も平行した。その 結果 90 年代後半のいわゆる就職水河期には, 大 卒新卒者の女性にはパートになるケースも現れ た。高校新卒者も派遣やパートを選択せざるをえ
ないケースが増加したのもこの時期である．新規 学卒者採用の縮小は, 若年非正規雇用者を大量に 生み出した.こうして, バブル後のリストラの進 行は 1990 年代を通じて失業率の漸増, 女性とと もに男性の非正規化を進行させた。

\section{2. 長時間労働の維持}

その一方で, 正規雇用が全廃されたわけではな い. 労働レジームの縮小された中核部分では, 能 力主義を導入する一方で働き方と処遇は大きくは 変えていない. つまり雇用保障とひきかえに，引 き続きあるいはむしろより長時間労働が課され た。

雇用調整として雇用コア部分を中心に長時間労 働傾向が顕著となっていく，雇用量の削減を人員 単位当たりの労働時間延長が一般化したのであっ た. 1985 年の労働基準法改正によって 8 時間労 働規制が一定期間の平均值とされたことは，週休 二日を実現する一方で定休日のない営業時間設定 や営業時間の延長を可能にした，先進工業国が労 働時間短縮を実現する一方で, 日本では 30 代男 性の 2 割近くが週 60 時間以上働いている長時間 労働の問題は 2010 年代になっても依然解決して いない（総務省『平成 23 年社会生活基本調査』）. 有給休暇の取得率も欧米では 100 パーセント近い のに, 日本では 50 パーセントに届いていない. そして, この時期以降新規雇用導入回避でもある 長時間労働傾向とともに, 職場のメンタルヘルス 問題が目立ち始める。コア労働者の量的な縮小 は, 非正規雇用という周辺部分の拡大と同時にコ ア労働者の労働時間増加によっても補完されてい る.

\section{3. 女性労働者の選択肢}

経済状況の厳しさと男性労働者のリストラは, この時期急激に共働きを拡大させている.

均等法以来, 正規雇用の総合職女性は男性並み の働き方を受け入れる場合に参入が許された。長 時間労働をいとわずコア内部職域でキャリアを形 成した総合職女性が結婚・出産・育児をするケー スも出現していた。しかしそれは多くの場合，女 
性の就労継続のための両立支援が充実した先進的 な大企業や教職・公務職場であった。あるいは子 どもの祖父母など親族ネットワークの支援やべ ビーシッターなど保育関連の大きなコスト負担を 前提としていた. 夫も総合職として働く共働き家 族は, 企業や組織の全体では少数者である. 〈スーパーウーマンとイクメンのカップル〉を可 能にしている公私の条件は背後に隠して, 子育て しながら就労継続できている事例の存在は大きく アピールされがちである.もちろん 1990 年代に は 1.57 ショックやエンゼルプランを追い風にし て育児介護休業法が制定され, 均等法によるポジ ティブ・アクションのもと両立支援, ワーク・ラ イフ・バランス政策は推進された。 90 年代以降 個別の職場においても働く女性全体に占める比率 としても, 共働きは相対的に漸増する部分であっ た。子育てしながら就労継続する部分の増加は,
確かに $\mathrm{M}$ 字型労働力率の「底」を上げた。しか しそれ以上に，子育て一段落後に非正規雇用とな る女性比率は高い（図 2)。つまり正規雇用での 就労継続より, 育児理由離職後非正規雇用での再 就職が選好されている.

関連法制度が 90 年代以降整備されていること は, 図 4 にも明らかである。しかし, 育児休業取 得，短時間勤務などの申請に応えることができる 企業職場は部分にとどまっていた。公務職場しか も女性が多い職場でも，妊娠出産や育児休業が 「職場に迷惑をかける」感覚が存在していた，正 規従業員の長時間労働, 残業業務の多さや育休交 代要員が配置されないことなどは, 90 年代から 00 年代の低迷する経済のなか職場の合理化の一 般的で主要な対応であった。管理職によるぎりぎ りの要員配置, 職場構成員相互の遠慮や配慮が交 錯し，両立支援やワーク・ライフ・バランス施策

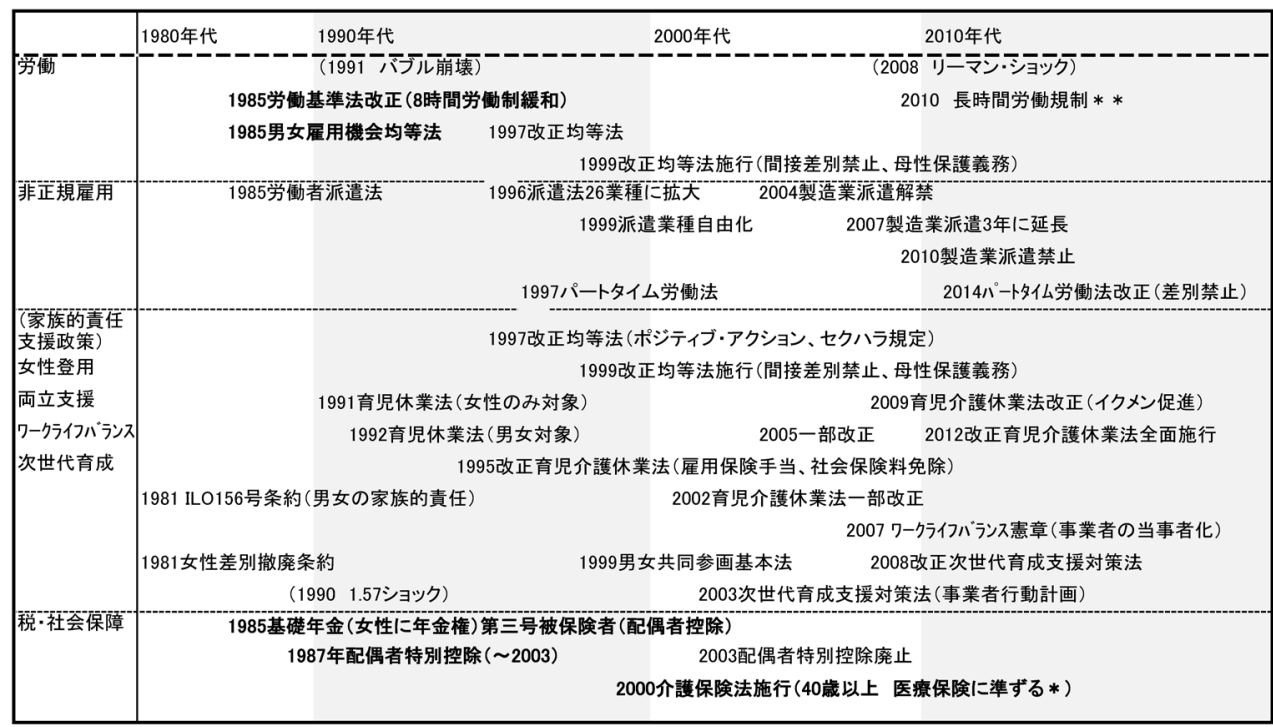

* 40 歳以上 65 歳未満 保険料支払：健康保険は世帯単位で被扶養者不払い, 国民健康保険世帯は人数分世帯主から 徵収. 65 歳以上男女とも個人単位徴収.

** 週 60 時間以上規制・超えると $50 \%$ 割増賃金, 時間単位有給休暇取得可能.

筆者が作成

家族的責任支援政策としては女性登用，両立支援，ワーク・ライフ・バランス，次世代育成支援などに関する政策が 該当する。

また労働政策や家族的責任支援政策に比べると社会保障政策は制度変化が少ない.

図 4 家族的責任支援政策と労働レジームをめぐる制度変遷 
特集 少子高齢化と日本型福祉レジーム：労働レジームと家族的責任

の職場運用に対する抵抗感を生み出している. 先 進施策を採用する企業において両立支援やワー ク・ライフ・バランスが中間管理職の査定項目と なり, 組織トップや組織的バックアップがあると きは確かに, 少しずつ前進していった。しかし全 体傾向では法制度や政策が, 罰則規定なしに努力 義務規定にとどまっている限り, 政策展開の実は 期待できなかった。

とはいえ, 次世代育成支援対策法による行動計 画の策定やくるみんマークによる企業認証は女性 の両立支援政策や男性の育児参加課題の広報周知 という啓発に事業者を関与させる意義はある。均 等法以降の労働レジームをめぐる制度政策をろり かえると, 全く変化がなかったわけではない、た だ, 労働レジームのコア部分は一定の変質を伴っ て縮小しながら 80 年代のまま残存している。そ の一方で, かつてのコアを周辺部分に転化させた ことによって, 90 年代以降, 急激にコアに対す る周辺部分, すなわち非正規労働者が拡大して いった.この状況は家族的責任を担う女性労働者 の働き方の選択肢がパートや派遣となることと表 裏をなしている。

\section{口 V. 周辺の拡大としてのパート基幹化 と派遣労働}

\section{1. パートの基幹化}

80 年代までの労働力不足基調では, 企業は労 働力を企業内部に保有確保することを至上命令と していた．ところが 91 年のバブル崩壊によって 状況は逆転する。余剩人員を企業内に保有しない 人員削減が推進された。より少ないコア労働者数 への転換に加え調整が容易な周辺労働者を企業外 部から随時調達する体制へとシフトする。それを 支えた大きな変化がパートの基幹化と派遣労働者 の拡大であった。この方向性はすでに 80 年代に 経済団体から今後の非正規労働市場の展望を示す 分析として提起されていた.すなわち 90 年代は グローバル化する経済と IT による急激な技術革 新が, バブル崩壊をきっかけにして従来ない頻度
と程度の雇用調整を企業活動に求めた時期であっ た。その雇用調整こそこれまで示した総合職人材 というコアの縮小と非正規雇用という周辺の拡大 である。

女性は正規雇用より非正規での増加が進む. 図 4 で示すように均等・均衡待遇のため差別的取り 扱いを禁止した 1997 年のパートタイム労働法制 定をはじめ, 労働者派遣法の規制緩和など非正規 雇用の制度整備が 1990 年代から急激に進んだ。 均等法成立により, コアの女性正規労働者の総合 職は男性に準じた扱いであったが，一般職女性は 1990 年代に徐々に非正規への置き換えが進んで いく. 労働者派遣法対象業種拡大に関する改正以 後, 派遣労働者の増加が加速する.職務単位で労 働者を派遣されるだけでなく，たとえばコールセ ンター業務などのように特定の部署全体をアウト ソーシングすることも一般化した，パートの基幹 化や業務アウトソーシングにより一般職の女性が フルタイム正規職でキャリア形成するルートはほ ぼ消滅した感があるのが 90 年代から 2000 年代で あった。

流通・小売を中心にパート労働拡大という非正 規雇用拡大が進むなか, パートの基幹化は 90 年 代から 00 年代に急激に進行している。 パートの キャリア形成を認めコア正規雇用が行ってきた職 務や職域をパートに代替させたのがパートの基幹 化である。パートは既婚女性が多く，税と保険料 について被扶養の枠を守ることを求める場合が多 数を占める.しかしパートの勤続年数が長くなる につれてその枠内でパートながらキャリアを積 み，管理的職務を担う人材を擁する職場や企業も 出現した．たとえばスーパーマーケットの場合, 1990 年代になると小規模店舗であれば店長だけ が正社員ということも珍しくない（乗杉・岡橋 2013). 企業のコアとなる中核の正規労働者の絶 対数を減少させ，低コストのパートに置き換える ことが，パートの基幹化によって実現されていく ようになる。 


\section{2. 派遣労働の拡大}

グローバル化が進行した 2000 年代, 雇用調整 としての非正規雇用の拡大は正規雇用の縮小とそ の縮小を周辺の非正規雇用拡大で補完し吸収する ことであった。この動きは, 1990 年代半ばから 派遣労働の規制緩和傾向に端的に表れる. 派遣労 働者の増加は, パート以上にその対象を幅広くし ていく設定を伴いながら, 労働者派遣法の規制緩 和を繰り返して推進された. かつて劣悪な労働条 件を規制するべく定められた規制が次々外され， 2004 年にはついに製造業での労働者派遣が合法 化されていった。

コアである正規雇用労働者を縮小し，さらにコ ア人材の雇用調整を回避するためにパートや派遣 労働者など周辺的人材が利用されることが常態化 したのが 2000 年以降の日本であるといえる．派 遣労働の相次ぐ規制緩和と範囲拡大により製造業 派遣，日雇い派遣と新しい展開が開始した。とく に人材派遣業は大手から小規模企業まで多くの新 規参入者が出現し, 90 年代半ばから数年の間に 売り上げを倍以上に拡大していった. 労働者派遣
を行うだけでなく，仕事と職場をパッケージ化し て, 企業のコア正規労働者職務を職場ごとアウト ソーシングするビジネスが拡大していた。

1985 年制定時に 16 業種に限定していた労働者 派遣法は, 1994 年には派遣労働者 50 万人, 人材 派遣売上げ 1 兆円, 96 年に業種 26 に拡大を経 て, 99 年に対象業務が原則自由化（製造, 建設, 医療を除く）された。2002 年には派遣業界の売 上げが 3 兆円を超え， 2004 年に製造業に派遣が 解禁される。一般派遣期間が 1 年から 3 年に延長 されたこともあり, 自動車や家電メーカーなど日 本の代表的企業が派遣労働者を前提とした企業活 動を展開した。その結果, 賃金水準の低さ, キャ リア形成が不可能な働き方であることに加えて, 派遣先が変動することにより生活基盤が脆弱とな る非正規労働者が急増していった．若年派遣労働 者のキャリア展望のなさは, その後, 中長期の日 本の労働市場にとってあまりに大きな課題をつき つけるようになる。その課題を集約したかのよう に起こったのが 2008 年製造業派遣社員による秋 葉原通り魔事件である。これを契機に，さすがに

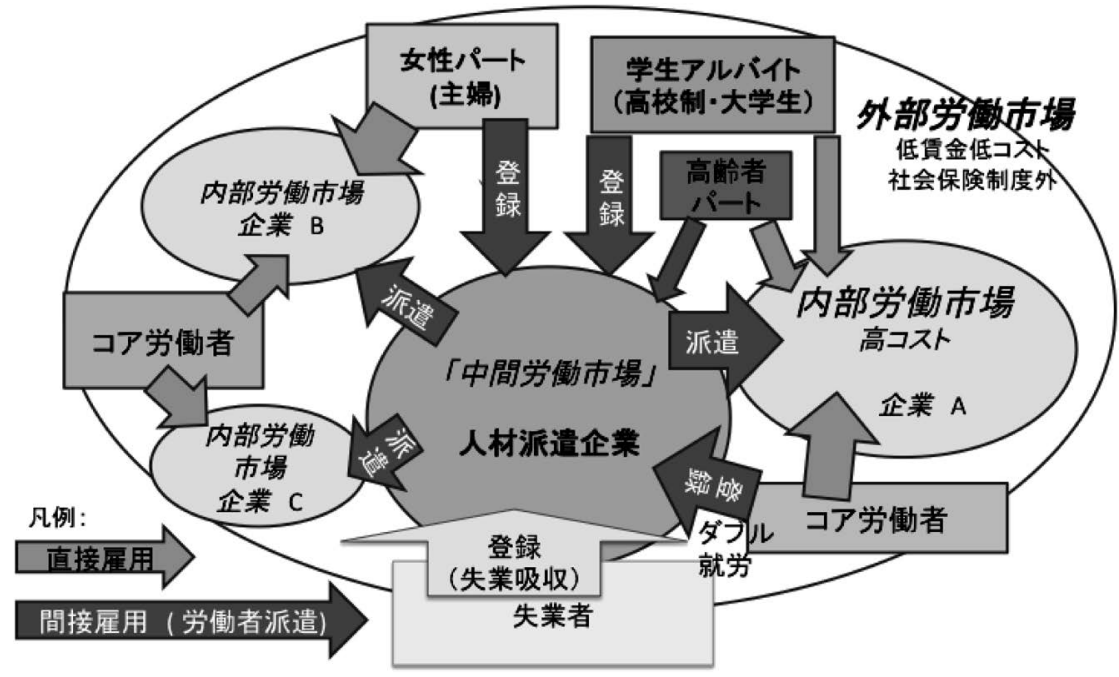

筆者作成.

本図は，直接雇用，間接雇用の流れと労働市場の関係を概念化している。1990年代以降，派遣労働は企業が直接に 労働者を雇用しない間接雇用の拡大であり, 企業内と外部労働市場の間に「中間労働市場」を発生させた。

図 5 非正規雇用としての間接雇用 
特集 少子高齢化と日本型福祉レジーム：労働レジームと家族的責任

過剩な緩和の見直しが始まり，2010年に労働者 派遣法が改正され, 製造業への派遣は原則禁止に なった。

派遣労働の急速な拡大は, コア労働者を縮小す ることによる失業者の発生拡大を緩和する機能を 果たしているという見方も可能となる. 図 5 で示 すように, 従来から直接雇用されていた女性パー トや学生アルバイトという非正規雇用のカテゴ リーは, 正規労働者の被扶養者である場合が多い 人々が構成していた. 80 年代までの労働レジー ムのもとであればコア労働者の被扶養者であった 人々である。しかし 90 年代以降, 先に示したよ うなコア労働者の縮小と周辺の拡大は, 非正規雇 用の新しいカテゴリーを形成した．つまり，仕事 があるときだけ労働者になるという企業に都合の よい雇用である．完全な失業者となる外部労働市 場でなく，また雇用コストの発生する内部労働市 場の労働者でもない. 労働市場の外部と内部の間 の「中間労働市場」として位置する非正規雇用力 テゴリーである。それに応えるような機能を与え られたのが派遣労働であった. 90 年代半ばから 若年層の失業率が, 他の年代以上に上昇する. 前 項でも触れたように新卒者採用が縮小された結果 である. 大学生以上に高校生の求人が縮小した。 その結果, 彼らが吸収されていったのが派遣労働 であった。 とくに 2000 年以降, 携帯電話の普及 から求人求職行動が変化して, 就職情報誌やイン ターネットを介して失業者を吸収していくように なる。そして, 派遣労働者は, 常用型でない登録 型派遣の場合, 登録することによって雇用される ことを待つという独特の労働市場に位置すること になる. 企業による直接雇用でなく, 人材派遣ビ ジネスを介した間接雇用の市場が確実に拡大して きた。それは失業者に対して労働市場での存在を 完全な失業者ではないが, しかし, 限定された期 間のみ雇用が与えられるという不安定な位置を与 えた。

他方, 派遣労働者を直接雇用することなく労働 力を利用できる企業にとって，パート以上に雇用
量調整が容易な労働力の存在の出現である.つま り派遣労働者という間接雇用にすれば企業は人事 管理や社員教育を行う必要がなく残業手当や有給 休暇を与える必要もなくなる。ささらに解雇が容易 にできるなど人件費を大幅に節約できる。つま り, 社会保険や雇用保険や退職金の負担をゼロに して低賃金にできるだけでなく，中長期の人間と しての生活や技能養成を顧慮することから企業を 解放してしまう雇用形態による働き方になってい る. 派遣労働者法による人材派遣ビジネスは, 人 間をあたかも「もの」として調達配置できる。ま た本来は失業者であるにもかかわらず，人材派遣 ビジネスに登録することによって, 雇用がない労 働者に労働市場の居場所を与えているともいえよ う。その意味で企業内でなく企業間の労衝市場で もない中間労働市場という表現のあいまいさは, 派遣労働者の不安定な地位を示している. 最低限 の労働基準の規制をはじめとする法制度によっ て, 労働条件, 賃金水準を遵守する仕組みが不可 欠である。もちろんその法制度には均等法や育児 介護休業法も含まれねばならない。しかし, 現状 の法令遵守はとても十分とはいえない.

口 VI. 労働レジームにおける制度と運用

このようにパートや派遣労働者という非正規雇 用拡大政策を採用することで，手厚い福利厚生や 社会保障へ連動する「日本型福祉レジーム」の枠 外の処遇を受ける労働者が増加することを 90 年 代以降の労働レジームは可能にした. 加えてパー トや派遣は, 基本的に有期雇用であるため流動性 が高い.すなわち 1991 年のバブル崩壊以降のい わゆる失われた 10 年ないしは 20 年の間に, 日本 の労働レジームは, フレキシブルな雇用調整が可 能で, 時間給, 社会保障給付低負担, 福利厚生な しで働く企業にとって低コストの労働力を，コア の縮小と周辺の拡大によって確保するという調整 を行ったといえる. 非正規雇用は, かつて若年, 女性，高齢者など属性分類から，「流動化した男 女」へ「多様化」し拡大した。 
多様で流動的な非正規雇用の出現は, 労働レ ジームの旧型日本的雇用から「新時代の日本的経 営」への転換である。旧型では, 男性に企業のコ アの安定型雇用を与える一方, 女性は周辺的流動 雇用と配置されていた。90 年代以降の新型では, 縮小されたコア部分を除き, 男女年齢を問わず周 辺となる非正規雇用労働者は多様化し流動化し た. 周辺は 80 年代には女性だけであったが, 90 年代以降, 若年労働者の失業率の上昇とともに男 性の周辺流入も増加した。 その意味で,「男性稼 ぎ手」になりうる男性は減少している。

しかしこれに対し「女性被扶養者」部分は, 引 き続き縮小することなく維持されている。 その根 拠の一つは, 女性パートの第 3 号被保険者の維持 の仕組, すなわち税制と年金, 医療, 介護保険な ど社会保障制度にある。 そしてもう一つの根拠 は, 育児と介護のケア労働を家族の内部で担当す るのが女性という働き方の現実である。ただ 2000 年の介護保険制度による公的社会保険制定 施行が高齢者ケア労働については社会サービス化 したが, 育児ケア労働は公的社会保険制度として は支援されていない.この点は, 子どもをもうけ る家族単位あるいは家計単位を構成するコアの男 性労働者にとっても, 周辺のパートや派遣の女性 労働者にとっても 2010 年以降も育児ケア労働は コスト負担と労力面で等しく切実である.

したがって日本の労働レジームは, 80 年代以 降も日本的雇用慣行のコア部分を縮小させなが ら, しかしその存続は維持し保証している.そし て同時により低コストの労働力確保のために, 1990 年代以降も周辺的非正規雇用を量的にも質 的にも拡大してきたのであった. コアも周辺もそ れぞれの根拠の一つを税と社会保障制度の被扶養 においていたからである.したがって, 家族的責 任のケア労働は, 「男性稼ぎ手と女性被扶養者」 の摇らぎながらの維持によって，とりわけ育児ケ ア労働を焦点とする〈分業型〉家族的責任は結果 として維持されている. 維持する根拠と力はこれ まで示したとおり労働レジームとしての働き方で
ある.すなわち，家族的責任である育児ケア労働 については男女の分業を前提に女性担当として, 男性がコアにおいて長時間労働，女性が周辺にお いて非正規雇用でケア労働と両立させるという働 き方である。

マクロ的には 90 年代以降, 図 4 で示したよう な女性登用政策や両立支援政策，さらには事業者 を当事者化するための次世代育成支援対策法によ る行動計画やワーク・ライフ・バランス関連政策 も 1990 年代からはケア労働と家族的責任支援と して政策展開している。法規制も2000 年以降, 徐々にではあるが, 努力義務規定から罰則規定へ 改正されている. また, 労働時間規制についても 長時間労働の是正や有給休暇取得奨励も推進され た。イクメンやカジダンというキーワードを用い てケア労働を積極的に担当し休暇を取得する男性 の出現をうながすことで, コア労働者の行動様式 を変えようとする休業法の改正もあった.

それでも, 2010 年以降の職場レベルの状況を みるとき, とりわけ男性の場合コア労働者の長時 間労働は減少していない. また, 周辺についても 非正規雇用の女性労働者が母性保護に基づく配慮 を求めたり育児休業取得申請しても, 許されず逆 に雇い止めされたりするマタニティ・ハラスメン トが指摘されるようになった。その背後には出産 育児を理由に無言で職場を去る非正規雇用の膨大 な女性労働者が確実に存在している. 正規雇用で も非正規雇用でも，そして女性でも男性でもケア 労働という家族的責任を担う労働者支援政策につ いて職場レベルの制度運用の停滞がうかがえる.

この停滞への対策は, トップ層による推進や中 間管理職への研修そして職場意識の啓発が繰り返 しアピールされ主張されてきている. しかし, 労 働レジーム全体が税・社会保障に根ざした「男性 稼ぎ手」と「女性被扶養者」の働き方を基準とす る限り職場の運用の停滞は継続する。停滞を変化 させるのは，まずなによりも第一に「女性被扶養 者」の根拠となる税制の被扶養に関する規定の改 正が必要である. 第二に長時間労働規制の徹底で 
ある．労働時間について罰則規定を設けて基準遵 守を徹底することは, 職場の確実な「運用」を確 実に変化させる。そして，第三に，現行の各種政 策とりわけ母性保護と休業取得について職場の確 実な「運用」を監視するシステムの構築と実行で ある。「運用」監視のためには現行の労働基準行 政に基づくきめ細かな罰則規定を設けることも必 要であろう。

労働レジームの中で働く人々の意識は, 時間は 要するとしても日々の制度運用が進めば確実に変 化する．法律は存在しても遵守する仕組みが十分 に機能していない局面が多い現在, 労働レジーム のミクロレベルでの職場内部の制度運用が変化す るとは考えられない。諸外国の事例と歴史的経緯 を踏まえた研究蓄積が存在する以上，家族的責任 とケア労働についてなすべき課題は理論的にも実 践的にもすでに明瞭である。それをめぐる法律も 制定されてきた。しかし，罰則規定および制度を 遵守する仕組みが存在しないか, 存在しても機能 不全に陥っているのが現在の日本の労働レジーム と家族的責任に関連する政策体系である。この現 状が生じた理由は，家族的責任に関連する法律を 遵守しないことが短期的には職場を構成する個々 人の利害に合致するという意識に支配されている 現実がある。とりわけ育児ケア労㗢への支援制度 の必要性の実感は, 男性はもとょり女性内部でも 共有されていない，世代や就労状況が異なる場 合，女性間でも育児ケア支援ニーズに対する共感 には温度差がある。この点は介護ケア労働と大き く異なる，介護保険制度は男女を問わず必ず直面 する老いに対して世代を超えた共感が労働運動の 中においても形成され, 公的保険制度の実現の原 動力になっていたからである. 育児ケア労働支援
への長期的視点に立つ社会意識が世代や性別さら には職種職域を超えて働く人々のなかで広範に共 有されるとき，家族的責任政策遵守の推進の困難 さが削減されるのかもしれない。

\section{【付 記】}

本論文は文部科学省科学研究費補助金（平成 $26 \sim 28$ 年度基盤研究（A）（海外学術調查）「ジェンダーの視点 から見た日本・韓国・ドイツの非正規労㗢の比較調査 研究」（研究代表者・横田伸子）に基づく研究成果の一 部である。

\section{【文献】}

服部良子，1993，「日本的経営下の女性労働と家族生活」 竹中恵美子編著『グローバル時代の労働と生活』ミ ネルヴァ書房.

， 1994，「家族の変貌と家事労働の社会化」竹 中恵美子編著『労働力の女性化— 21 世紀へのパラ ダイム』有斐閣.

—, 1996, 「女性の労㗢問題」石畑良太郎・佐野 稔編『現代の社会政策第 3 版』有斐閣.

， 1997，「家族的責任」玉井金五・大森真紀編 著『社会政策を学ぶ人のために』世界思想社.

一，2007，「家族的責任」玉井金五・大森真紀編 著『三訂社会政策を学ぶ人のために』世界思想社.

乗杉澄夫・岡橋充明, 2013, 『ホワイトカラーの仕事 キャリア—ースーパーマーケット店長の管理』法律 文化社.

大森真紀，2014，『世紀転換期の女性労働——1990 年代〜 2000 年代』法律文化社.

塩田咲子，2000，『日本の社会政策とジェンダー』日本 評論社.

総務省『平成 23 年社会生活基本調査』, 総務省ホーム ページ（2015 年 1 月 25 日取得 http://www.stat.go.jp/ data/shakai/2011/index.htm).

竹中恵美子，2012a，『竹中恵美子著作集 II 戦後女性 労㗢史論』明石書店.

—，2012b，『竹中恵美子著作集 VI 家事労働 （アンペイド・ワーク）論』明石書店. 